\title{
Association Study between Norepinephrine Transporter Gene Polymorphism and Schizophrenia in a Korean Population
}

\author{
Mira Choo, Jung-A Hwang, Sang Won Jeon, So-Young Oh, \\ Ho-kyoung Yoon, Heon-Jeong Lee, and Yong-Ku Kim ${ }^{\bowtie}$ \\ Department of Psychiatry, College of Medicine, Korea University, Seoul, Republic of Korea
}

\begin{abstract}
Objective We aimed to investigate possible associations between three norepinephrine transporter gene (SLC6A2) single nucleotide polymorphisms (T182C, A3081T, and G1287A) and schizophrenia. Also, we investigated the relationships of those polymorphisms with clinical severity and characteristics of schizophrenia.

Methods Participants were 220 schizophrenia patients in the acute phase and 167 healthy controls. The genotype, allele frequency, and haplotype of each group were analyzed for T182C, A3081T, and G1287A polymorphisms. Of the 220 schizophrenia patients, 163 patients were evaluated with the Positive and Negative Syndrome Scale (PANSS) and the Korean version of the Calgary depression scale for schizophrenia (K-CDSS) at baseline.

Results We found no significant differences between the schizophrenia patient group and the control group in genotype distribution or allele frequency of the three tested polymorphisms. Likewise, we could not find any significant differences in genotype or allele frequency by analyzing according to gender. In the haplotype study, no significant association emerged between specific haplotype combinations and schizophrenia. We also found no association between clinical scales (PANSS and K-CDSS) and the studied polymorphisms.

Conclusion Our results suggest that the investigated polymorphisms of the NET gene are not associated with susceptibility to schizophrenia or its clinical features in a Korean population. However, this study remains significant because it is the first haplotype study to investigate associations between NET gene (SLC6A2) single nucleotide polymorphisms and schizophrenia in a Korean population. Future research with a larger sample size and more genetic markers is needed to replicate our results.

Psychiatry Investig 2015;12(4):551-558
\end{abstract}

Key Words NET gene, Single nucleotide polymorphism, Schizophrenia, Gene.

\section{INTRODUCTION}

Norepinephrine is one of the neurotransmitters that has been implicated in the pathogenesis of schizophrenia. ${ }^{1}$ Norepinephrine is an important chemical messenger in the central and peripheral nervous systems, and it regulates mood, arousal, learning, and autonomic functions. ${ }^{2}$ Norepinephrine functions are mediated by norepinephrine binding proteins, such as adrenergic receptors and norepinephrine transporter (NET; SLC6A2). The action of norepinephrine is regulated mainly by its uptake into neurons via NET.,3 The NET genes

Received: October 3, 2014 Revised: January 24, 2015

Accepted: February 12, 2015 Available online: September 30, 2015

$\triangle$ Correspondence: Yong-Ku Kim, MD, PhD

Department of Psychiatry, College of Medicine, Korea University, 123 Jeokgeum-ro, Danwon-gu, Ansan 15355, Republic of Korea

Tel: +82-31-412-5140, Fax: +82-31-412-5144, E-mail: yongku@korea.ac.kr

(a) This is an Open Access article distributed under the terms of the Creative Commons Attribution Non-Commercial License (http://creativecommons.org/licenses/by$\mathrm{nc} / 3.0$ ) which permits unrestricted non-commercial use, distribution, and reproduction in any medium, provided the original work is properly cited. play an important role in central nervous monoaminergic homeostasis, and genetic variation in human NET can influence noradrenergic signaling in the brain.

Human NET is a NaCl-dependent substrate-specific transporter, ${ }^{4}$ and its reuptake activity is regulated by second messengers and hormones. ${ }^{5,6}$ The gene coding human NET has been assigned to $16 \mathrm{q} 12.2 .^{7}$ It consists of $15 \mathrm{exons}^{8,9}$ and is a 617 -amino acid protein that shows similarity in amino acid sequence to the dopamine transporter and the serotonin transporter. ${ }^{10-13} \mathrm{Kim}$ et al. ${ }^{14}$ reported that the 5'flanking promoter region of the NET gene is approximately $4.7 \mathrm{~kb}$ and contains an additional intron of $476 \mathrm{bp}$. Several potential transcriptional elements are located in this intron and could be important enhancers of transcription and correct splicing.

Several studies have tried to show that functional deficits of the NET gene can cause psychiatric diseases including mood disorder, anxiety disorder, substance disorder, and ADHD. It is thought that noradrenergic dysregulation plays an important role in the pathophysiology of those disorders, 
and agents related to noradrenergic function can improve the symptoms. ${ }^{15-17}$ Regarding schizophrenia, however, few reports have been made.

Therefore, we focused on the possibility that the NET gene plays a role in schizophrenia. We investigated three NET single nucleotide polymorphisms (SNPs), T182C (rs2242446), A3081T (rs28386840), and G1287A, to determine whether they play a role in schizophrenia. The T182C and A3081T polymorphisms, located in the 5 flanking promoter region of the NET gene, could lead to altered transcriptional activity by changing the DNA structure. ${ }^{18}$ Stöber et al. ${ }^{19}$ systemically screened the whole coding region of the NET gene and identified 13 DNA sequence variants (five infrequent missense, three silent, and five intronic mutations). Of these variants, a high heterozygosity compared to other markers was observed in the G1287A polymorphism (rs5569), located in exon 9 of the NET gene. Therefore, we tested the hypothesis that the NET gene is involved in the development of schizophrenia or its clinical features. We also hypothesized that the gender difference in clinical course would be related to the differences in the genetic pattern of the disease, and therefore, we planned to examine gender differences in all analyses.

\section{METHODS}

\section{Subjects}

We recruited 220 patients with schizophrenia who met the criteria of the Diagnostic and Statistical Manual of Mental Disorders, fourth edition (DSM-IV) ${ }^{20}$ from subjects newly admitted to the Korea University Medical Center Ansan Hospital for acute psychotic symptoms between August 2006 and April 2010. Initial psychiatric interviews were conducted by trained psychiatrists using the Structured Clinical Interview for DSM-IV Axis I Disorders (SCID-I). ${ }^{21}$ The subjects with comorbid diagnoses of schizoaffective disorder, mood disorders, substance-related disorders, or dementia were excluded.

The normal controls consisted of 167 healthy individuals recruited through advertisement. These controls were screened with the SCID-I, non-patient edition. ${ }^{21}$ Subjects who had any medical/psychiatric illness, familial history of mental illness, or who had scores of $\geq 10$ on the Beck Depression Inventory $(\mathrm{BDI})^{22}$ or $\geq 40$ on the State-Trait Anxiety Inventory (STAI) ${ }^{23}$ were excluded.

To assess the severity of a patient's psychiatric symptoms, patients were interviewed by trained psychiatrists using the Positive and Negative Syndrome Scale (PANSS) ${ }^{24}$ and the Korean version of the Calgary depression scale for schizophrenia (K-CDSS). PANSS was published in 1987 by Stanley Kay et al. and is used to measure the symptom severity of patients with schizophrenia. CDSS was developed by Addington et al. ${ }^{25}$ to evaluate the level of depression in schizophrenia patients. This test is useful in evaluating both relapsed and remitted patients and appears sensitive to change. The Korean version of CDSS was standardized by Kim et al..$^{26}$ in 2005 and is known to be highly valid and reliable. Treatment dose was determined considering clinical improvement and side effects and was 200-800 $\mathrm{mg}$ of chlorpromazine equivalent.

Written informed consent was obtained from all subjects (or caretakers of the patients), and the study protocol was approved by the Ethics Committee of Korea University Ansan Hospital.

\section{DNA analysis and genotyping}

Genotypes of the NET gene were analyzed in 220 patients and 167 controls. Genomic DNA was extracted from leukocytes using a commercial DNA extract kit, the Wizard Genomic DNA purification kit (Promega, Madison, WI, USA). Samples were amplified using a thermocycler (GeneAmp PCR system 2700, Applied Biosystems, Foster City, CA, USA).

The NET T182C SNP was genotyped by the polymerase chain reaction (PCR) and restriction fragment length polymorphism (RFLP) methods according to the protocol originally described by Inoue et al. ${ }^{15}$ In brief, the amplification mixture contained $0.5 \mu \mathrm{L}$ of $100 \mathrm{ng} / \mu \mathrm{L}$ DNA, $2.5 \mu \mathrm{L}$ of $10 \mathrm{x}$ buffer, $0.5 \mu \mathrm{L}$ of $10 \mathrm{mM}$ dNTP mixture, $1 \mu \mathrm{L}$ primer, $19.375 \mu \mathrm{L}$ distilled water, and $0.125 \mu \mathrm{L}$ DNA polymerase (Solgent, Korea). PCR conditions began with an initial $5 \mathrm{~min}$ at $95^{\circ} \mathrm{C}$, and each cycle consisted of $30 \mathrm{~s}$ at $95^{\circ} \mathrm{C}, 30 \mathrm{~s}$ at $60^{\circ} \mathrm{C}$, and 30 $s$ at $72^{\circ} \mathrm{C}$ for 35 cycles. After a final $10 \mathrm{~min}$ at $72^{\circ} \mathrm{C}$, the reaction was terminated at $4^{\circ} \mathrm{C}$. The amplified DNA was digested with the restriction enzyme StyI (New England Biolabs), which cuts at the - $182 \mathrm{C}$ site, and the product was electrophoresed in 3\% agarose gel and stained with ethidium bromide. Homozygous genotypes were identified by the presence of a single $175 \mathrm{bp}$ band $(\mathrm{T} / \mathrm{T})$ or bands of 145 and $30 \mathrm{bp}(\mathrm{C} / \mathrm{C})$. The heterozygous genotype (T/C) displayed all three band sizes.

The NET A3081T SNP was genotyped by PCR, according to the protocol originally described by Suzuki et al. ${ }^{27}$ The amplification mixture conditions were the same as with T182C. After an initial $5 \mathrm{~min}$ at $95^{\circ} \mathrm{C}$, each cycle consisted of $30 \mathrm{~s}$ at $95^{\circ} \mathrm{C}, 30 \mathrm{~s}$ at $59^{\circ} \mathrm{C}$, and $30 \mathrm{~s}$ at $72^{\circ} \mathrm{C}$ for 36 cycles. After a final $10 \mathrm{~min}$ at $72^{\circ} \mathrm{C}$, the reaction was terminated at $4^{\circ} \mathrm{C}$. The amplified DNA was digested with the restriction enzyme BsrsI (New England Biolabs), which cuts at the -3081A site, and the product was electrophoresed in 3\% agarose gel and stained with ethidium bromide. Homozygous genotypes were identified by the presence of 198 and 96 bp bands (A/A) or a single $294 \mathrm{bp}$ band $(\mathrm{T} / \mathrm{T})$. The heterozygous genotype 
Table 1. Demographic data of schizophrenia patients and normal controls

\begin{tabular}{|c|c|c|c|}
\hline & Normal controls $(\mathrm{N}=167)$ & Schizophrenia patients $(\mathrm{N}=220)$ & p-value \\
\hline Sex (male/female)* & $64 / 103$ & $97 / 123$ & $0.254^{\ddagger}$ \\
\hline Age [years, mean $(\mathrm{SD})]^{\dagger}$ & $34.79(8.82)$ & $33.10(9.88)$ & $0.076^{\ddagger}$ \\
\hline Age at onset [years, mean (SD)] & & $27.44(9.89)$ & \\
\hline Total duration of illness [months, mean(SD)] & & $76.44(9.97)$ & \\
\hline Number of admissions & & $1.15(1.91)$ & \\
\hline \multicolumn{4}{|l|}{ PANSS $[$ mean(SD)]§ } \\
\hline Positive & & $25.72(6.85)$ & \\
\hline Negative & & $23.00(7.94)$ & \\
\hline General & & $48.10(10.85)$ & \\
\hline Total & & $96.816(21.16)$ & \\
\hline CDSS§ & & $7.215(5.29)$ & \\
\hline
\end{tabular}

${ }^{*} \chi^{2}$ test, ${ }^{+i n d e p e n d e n t ~ t-t e s t, ~}{ }^{\ddagger}$ not significant, ${ }^{\circ}$ of 220, 163 patients were evaluated by PANSS and CDSS. PANSS: Positive and Negative Syndrome Scale, CDSS: Calgary depression scale for schizophrenia

(A/T) displayed all three band sizes.

The NET G1287A SNP was genotyped by PCR according to the protocol originally described by Kazuyuki Inoue et al. The amplification mixture conditions were the same as with T182C. After an initial $5 \mathrm{~min}$ at $95^{\circ} \mathrm{C}$, each cycle consisted of $30 \mathrm{~s}$ at $95^{\circ} \mathrm{C}, 30 \mathrm{~s}$ at $55^{\circ} \mathrm{C}$, and $30 \mathrm{~s}$ at $72^{\circ} \mathrm{C}$ for 36 cycles. After a final $10 \mathrm{~min}$ at $72^{\circ} \mathrm{C}$, the reaction was terminated at $4^{\circ} \mathrm{C}$. The amplified DNA was digested with the restriction enzyme Sau96I (New England Biolabs), which cuts at the 1287G site, and the product was electrophoresed in 3.7\% agarose gel and stained with ethidium bromide. Homozygous genotypes were identified by the presence of $113,79,28$, and 21 bp bands (G/G) or bands of 113,100 , and 28 bp (A/A). The heterozygous genotype (G/A) displayed all 5 band sizes (the 28 and $21 \mathrm{bp}$ fragments were undetectable because of their small size).

\section{Statistical analysis}

The presence of Hardy-Weinberg equilibrium was tested using a $\chi^{2}$ test for goodness of fit. Allele and genotype frequencies in patients with schizophrenia and healthy controls were also evaluated using the $\chi^{2}$ test. The pattern of linkage disequilibrium (LD) was investigated for the patient and control groups. Haplotype analysis was performed for the evaluation of haplotype association.

We also examined group differences in the PANSS and KCDSS scores of acute-phase patients related to the possession of specific alleles of the three polymorphisms using an independent $\mathrm{t}$-test.

These analyses were performed using the Statistical Package for the Social Sciences (SPSS) for Windows (version 21.0; SPSS Inc., Chicago, IL, USA) and SNP analyzer (Istech, Seoul, Republic of Korea). The level of statistical significance was set at $\mathrm{p}$-value $<0.05$.

\section{RESULTS}

\section{Demographic data}

Demographic data on patients and controls are summarized in Table 1. The mean age of schizophrenia patients was 33.10 (9.884) years, and the mean age of the control group was 34.79 (8.815) years. In patients with schizophrenia, the age of disease onset was 27.44 (9.89) years, the duration of illness was 76.44 (9.97) years, and the number of admissions was 1.15 (1.91). There was no significant difference in the mean age or sex between patients with schizophrenia and control subjects. The initial PANSS total score and positive, negative, and general subscores were 96.816 (21.159) and 25.72 (6.845), 23.00 (7.944), 48.10 (10.853), respectively (Table 1 ).

\section{Genotype and allele distribution}

The distributions of the T182C, A3081T, and G1287A polymorphisms in the patients and control groups were in agreement with the Hardy-Weinberg equilibrium and were as follows: T182C (patients, $\chi^{2}=0.284, \mathrm{df}=1, \mathrm{p}$-value $=0.594$; controls, $\chi^{2}=0.094, \mathrm{df}=1, \mathrm{p}=0.759$; total, $\chi^{2}=0.041, \mathrm{df}=1, \mathrm{p}$ value $=0.839$ ); A3081T (patients, $\chi^{2}=0.326, \mathrm{df}=1, \mathrm{p}$-value $=$ 0.568 ; controls, $\chi^{2}=0.055, \mathrm{df}=1, \mathrm{p}$-value $=0.815$; total, $\chi^{2}=0.322$, $\mathrm{df}=1, \mathrm{p}$-value $=0.570$ ); and G1287A (patients, $\chi^{2}=0.902, \mathrm{df}=1$, $\mathrm{p}$-value $=0.342$; controls, $\chi^{2}=0.068, \mathrm{df}=1, \mathrm{p}=0.795$; total, $\chi^{2}=0.377, \mathrm{df}=1, \mathrm{p}$-value $=0.539$ ).

Comparing the group of schizophrenia patients with the control group, we found no differences in the genotype or allele distribution. When the male and female subjects were analyzed separately, we also found no significant association of these three polymorphisms with schizophrenia (Table 2, 3, and 4). To consider multiple comparison problem, we obtained p-value after Bonferroni correction and found no sig- 
Table 2. Genotype and allele frequencies in schizophrenia patients and normal controls in total

\begin{tabular}{|c|c|c|c|c|c|c|c|c|c|c|}
\hline \multirow[b]{2}{*}{$\mathrm{T} 182 \mathrm{C}$} & \multicolumn{3}{|c|}{ Genotype distribution } & \multicolumn{2}{|c|}{ Allele frequency (\%) } & \multirow{2}{*}{$\frac{\chi^{2}}{0.467}$} & \multirow{2}{*}{$\begin{array}{c}\mathrm{p} \text {-value } \\
0.494\end{array}$} & \multirow{2}{*}{$\begin{array}{c}\mathrm{p} \text {-value* } \\
1\end{array}$} & \multirow{2}{*}{$\begin{array}{c}\text { OR } \\
1.109\end{array}$} & \multirow{2}{*}{$\begin{array}{c}95 \% \text { CI } \\
0.824-1.495\end{array}$} \\
\hline & $\mathrm{T} / \mathrm{T}$ & $\mathrm{T} / \mathrm{C}$ & $\mathrm{C} / \mathrm{C}$ & $\mathrm{T}$ & $\mathrm{C}$ & & & & & \\
\hline Patients & 98 & 95 & 27 & $290(66.1 \%)$ & $150(33.9 \%)$ & & & & & \\
\hline Controls & 67 & 79 & 21 & $214(63.8 \%)$ & $120(36.2 \%)$ & & & & & \\
\hline A3081T & $\mathrm{A} / \mathrm{A}$ & $\mathrm{A} / \mathrm{T}$ & $\mathrm{T} / \mathrm{T}$ & A & $\mathrm{T}$ & 0.627 & 0.429 & 1 & 1.122 & $0.844-1.491$ \\
\hline Patients & 58 & 114 & 48 & $230(52.3 \%)$ & $210(47.7 \%)$ & & & & & \\
\hline Controls & 40 & 85 & 42 & $164(49.4 \%)$ & $170(50.6 \%)$ & & & & & \\
\hline G1287A & $\mathrm{G} / \mathrm{G}$ & $\mathrm{G} / \mathrm{A}$ & $\mathrm{A} / \mathrm{A}$ & G & A & 1.484 & 0.223 & 0.699 & 0.823 & $0.602-1.126$ \\
\hline Patients & 106 & 89 & 25 & $300(68.4 \%)$ & $140(31.6 \%)$ & & & & & \\
\hline Controls & 87 & 68 & 12 & $242(72.5 \%)$ & $92(27.5 \%)$ & & & & & \\
\hline
\end{tabular}

*p-value after Bonferroni correction

Table 3. Genotype and allele frequencies in male schizophrenia patients and male normal controls

\begin{tabular}{|c|c|c|c|c|c|c|c|c|c|c|}
\hline \multirow[b]{2}{*}{$\mathrm{T} 182 \mathrm{C}$} & \multicolumn{3}{|c|}{ Genotype distribution } & \multicolumn{2}{|c|}{ Allele frequency (\%) } & \multirow{2}{*}{$\frac{\chi^{2}}{0.715}$} & \multirow{2}{*}{$\frac{p \text {-value }}{0.398}$} & \multirow{2}{*}{$\frac{\mathrm{p} \text {-value* }}{1}$} & \multirow{2}{*}{$\frac{\text { OR }}{0.814}$} & \multirow{2}{*}{$\begin{array}{c}95 \% \text { CI } \\
0.505^{-1.312}\end{array}$} \\
\hline & $\mathrm{T} / \mathrm{T}$ & $\mathrm{T} / \mathrm{C}$ & $\mathrm{C} / \mathrm{C}$ & $\mathrm{T}$ & $\mathrm{C}$ & & & & & \\
\hline Patients & 48 & 40 & 9 & $136(70.1 \%)$ & $58(29.9 \%)$ & & & & & \\
\hline Controls & 28 & 28 & 8 & $84(65.6 \%)$ & $44(34.4 \%)$ & & & & & \\
\hline $\mathrm{A} 3081 \mathrm{~T}$ & $\mathrm{~A} / \mathrm{A}$ & $\mathrm{A} / \mathrm{T}$ & $\mathrm{T} / \mathrm{T}$ & $\mathrm{A}$ & $\mathrm{T}$ & 0.009 & 0.926 & 1 & 1.022 & $0.654-1.597$ \\
\hline Patients & 24 & 51 & 22 & $98(51.0 \%)$ & $96(49.0 \%)$ & & & & & \\
\hline Controls & 17 & 32 & 15 & $66(51.6 \%)$ & $62(48.4 \%)$ & & & & & \\
\hline G1287A & $\mathrm{G} / \mathrm{G}$ & $\mathrm{G} / \mathrm{A}$ & $\mathrm{A} / \mathrm{A}$ & G & A & 0.003 & 0.955 & 1 & 0.986 & $0.6-1.62$ \\
\hline Patients & 52 & 36 & 9 & $140(72.2 \%)$ & $54(27.8 \%)$ & & & & & \\
\hline Controls & 33 & 26 & 5 & $92(71.9 \%)$ & $36(28.1 \%)$ & & & & & \\
\hline
\end{tabular}

*p-value after Bonferroni correction

Table 4. Genotype and allele frequencies in female schizophrenia patients and female normal controls

\begin{tabular}{|c|c|c|c|c|c|c|c|c|c|c|}
\hline \multirow[b]{2}{*}{$\mathrm{T} 182 \mathrm{C}$} & \multicolumn{3}{|c|}{ Genotype distribution } & \multicolumn{2}{|c|}{ Allele frequency (\%) } & \multirow{2}{*}{$\begin{array}{c}\chi^{2} \\
0.007\end{array}$} & \multirow{2}{*}{$\begin{array}{c}\mathrm{p} \text {-value } \\
0.932\end{array}$} & \multirow{2}{*}{$\begin{array}{c}\mathrm{p} \text {-value* } \\
1\end{array}$} & \multirow{2}{*}{$\begin{array}{c}\text { OR } \\
0.984\end{array}$} & \multirow{2}{*}{$\begin{array}{c}95 \% \mathrm{CI} \\
0.671-1.443\end{array}$} \\
\hline & $\mathrm{T} / \mathrm{T}$ & $\mathrm{T} / \mathrm{C}$ & $\mathrm{C} / \mathrm{C}$ & $\mathrm{T}$ & $\mathrm{C}$ & & & & & \\
\hline Patients & 50 & 55 & 18 & $154(63.0 \%)$ & $92(37.0 \%)$ & & & & & \\
\hline Controls & 39 & 51 & 13 & $128(62.6 \%)$ & $78(37.4 \%)$ & & & & & \\
\hline A3081T & $\mathrm{A} / \mathrm{A}$ & $\mathrm{A} / \mathrm{T}$ & $\mathrm{T} / \mathrm{T}$ & $\mathrm{A}$ & $\mathrm{T}$ & 1.21 & 0.271 & 0.814 & 0.812 & $0.561-1.177$ \\
\hline Patients & 34 & 63 & 26 & $132(53.3 \%)$ & $114(46.7 \%)$ & & & & & \\
\hline Controls & 27 & 53 & 23 & $106(51.9 \%)$ & $100(48.1 \%)$ & & & & & \\
\hline G1287A & $\mathrm{G} / \mathrm{G}$ & $\mathrm{G} / \mathrm{A}$ & $\mathrm{A} / \mathrm{A}$ & G & A & 2.836 & 0.092 & 0.277 & 1.414 & $0.944-2.118$ \\
\hline Patients & 54 & 53 & 16 & $160(65.4 \%)$ & $86(34.6 \%)$ & & & & & \\
\hline Controls & 54 & 42 & 7 & $150(72.8 \%)$ & $56(27.2 \%)$ & & & & & \\
\hline
\end{tabular}

*p-value after Bonferroni correction

nificant association.

\section{Linkage disequilibrium and haplotype analysis}

The LD test revealed that LD was moderately significant between $\mathrm{T} 182 \mathrm{C}$ and $\mathrm{A} 3081 \mathrm{~T}\left(\left|\mathrm{D}^{\prime}\right|=0.702, \mathrm{r}^{2}=0.275\right.$, $\mathrm{p}$-value $=$ $<10^{-5}$ ) but not between A3081T and G1287A or between T182C and G1287A (Table 5). Even though we found no significant LD related with G1287A, we performed a three-locus haplotype analysis. A total of eight haplotype combina- tions were calculated. Of the eight combinations, only six haplotype combinations with a frequency of at least 5 percent were included in the analysis: T182C-A3081T-G1287A in order T-A-G, C-T-G, T-T-G, C-T-A, T-A-A, T-T-A. The haplotype analysis revealed no significant association between haplotypes and risk for schizophrenia (Table 6).

When male and female subjects were analyzed separately, the $\mathrm{LD}$ test revealed that $\mathrm{LD}$ was also moderately significant between T-182C and A-3081T in both sexes (Table 5). In the 


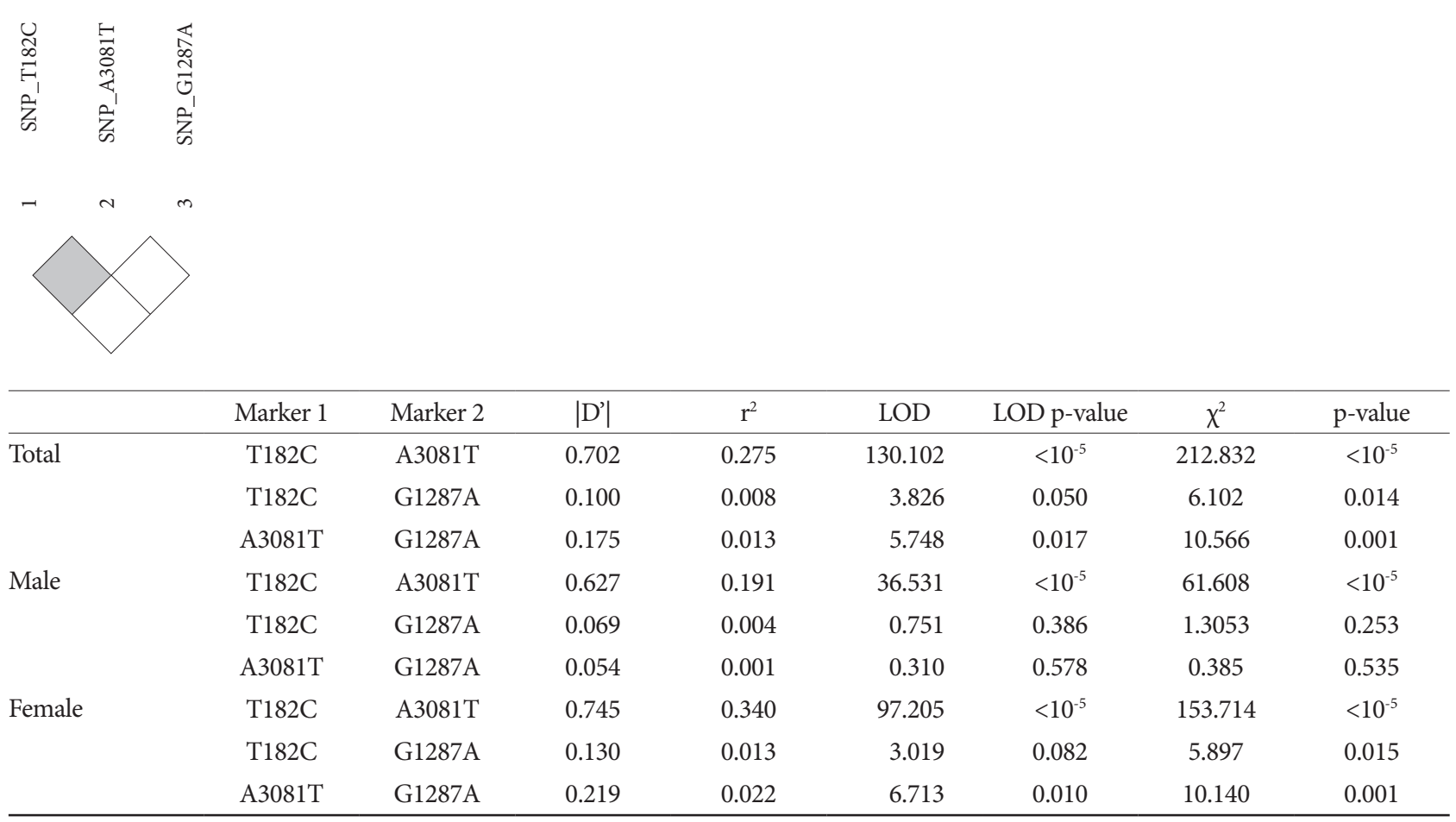

NET: norepinephrine transporter, LD: linkage disequilibrium, SNP: single necleotide polymorphism

haplotype analysis according to sex, we found no significant association among haplotype combinations.

\section{Clinical assessment}

The symptomatic characteristics of acute-phase schizophrenia were determined using PANSS and K-CDSS. Of 220 schizophrenia patients, 163 patients were assessed by PANSS and K-CDSS. We examined the effects of the T182C, A3081T, and G1287A SNPs on these clinical scales using an independent t-test.

No significant differences emerged in most of the analysis (Table 7). In the association analysis of G1287A SNPs, patients with the A/A genotype $(n=20)$ showed significantly higher K-CDSS score than patients with the G/A or G/G genotype ( $p$-value $=0.024)$ (Table 7$)$. Because of the small sample size, analysis according to gender was not performed.

\section{DISCUSSION}

Specific genes and relevant DNA sequence variations involved in the pathogenesis of schizophrenia have not yet been identified. Molecular genetic studies on schizophrenia have suggested that some genes related to the dopaminergic or noradrenergic system could be etiologic factors of schizophrenia, ${ }^{28}$ but the NET gene has received relatively little attention in this regard.
If NET is related to the pathogenesis of schizophrenia, we can consider some possibilities according to the symptom profile. First, NET dysregulation could be related to dopaminergic overflow causing psychotic symptoms, mainly in the temporal lobe. Also, NET dysregulation could play a role in negative deficit symptoms, even though the mechanism of deficit symptoms in schizophrenia is not fully understood. Siuta et al. ${ }^{29}$ reported that dysregulation of the norepinephrine transporter sustains cortical hypodopaminergia and schizophrenia-like behavior in neuronal rictor null mice, but we do not have clear evidence that NET plays an important role in catecholamine reuptake in the temporal or limbic areas, which are related to psychotic symptoms in schizophrenia. On the contrary, NET is mainly involved with noradrenergic and dopaminergic action in the frontal lobe. Considering the multiplicity of the clinical presentation of schizophrenia, including cognitive decline, loss of spontaneity, and intermittent loss of control, NET should be considered as a factor in schizophrenia.

Several studies have investigated the association between NET gene polymorphisms and various psychiatric disorders, including major depression, bipolar disorder, and substance dependence. However, most of them demonstrated no association with the disease. For schizophrenia, only a few association studies have been performed. Leszczyńska-Rodziewicz et al. ${ }^{1}$ investigated an association between G1287A and schizo- 
Table 6. Three-locus haplotype distributions in schizophrenia patients and controls

\begin{tabular}{|c|c|c|c|c|c|c|c|c|}
\hline \multirow{2}{*}{$\begin{array}{l}\text { Haplotype combination } \\
182 \mathrm{~T} / \mathrm{C}-3081 \mathrm{~A} / \mathrm{T}-1287 \mathrm{G} / \mathrm{C}\end{array}$} & \multicolumn{3}{|c|}{ Frequency (\%) } & \multicolumn{5}{|c|}{ Statistics } \\
\hline & Controls & Patients & Overall & OR & $95 \% \mathrm{CI}$ & $\mathrm{p}$-value & p-value* & $\chi^{2}$ \\
\hline T-A-G & 34.670 & 34.512 & 34.538 & 1.007 & $0.752-1.348$ & 0.962 & 1 & 0.002 \\
\hline C-T-G & 19.957 & 17.276 & 18.395 & 0.860 & $0.583-1.270$ & 0.449 & 1 & 0.572 \\
\hline T-T-G & 14.542 & 12.727 & 13.238 & 0.805 & $0.522-1.240$ & 0.324 & 1 & 0.972 \\
\hline C-T-A & 10.604 & 12.223 & 11.193 & 1.570 & $0.900-2.740$ & 0.11 & 0.879 & 2.556 \\
\hline T-A-A & 9.065 & 11.554 & 11.187 & 1.002 & $0.673-1.493$ & 0.991 & 1 & 0.000 \\
\hline T-T-A & 5.495 & 6.674 & 6.147 & 1.285 & $0.703-2.346$ & 0.414 & 1 & 0.667 \\
\hline
\end{tabular}

*p-value after Bonferroni correction

Table 7. PANSS (positive, negative, general, and total score) and K-CDSS associated with the T182C, A3081T, and G1287A polymorphisms of the NET gene (SLC6A2) in a sample of 163 schizophrenia patients

\begin{tabular}{|c|c|c|c|}
\hline & \multicolumn{3}{|c|}{$\mathrm{T} 182 \mathrm{C}$} \\
\hline & $\mathrm{C} / \mathrm{C}(\mathrm{N}=19)$ & $\mathrm{C} / \mathrm{T}(\mathrm{N}=74)+\mathrm{T} / \mathrm{T}(\mathrm{N}=70)$ & p-value \\
\hline PANSS total score & $92.263 \pm 20.698$ & $97.417 \pm 21.216$ & 0.320 \\
\hline PANSS positive score & $23.526 \pm 5.440$ & $26.996 \pm 6.973$ & 0.138 \\
\hline PANSS negative score & $20.263 \pm 7.549$ & $23.361 \pm 7.950$ & 0.110 \\
\hline PANSS general score & $48.474 \pm 11.000$ & $48.0487 \pm 10.872$ & 0.873 \\
\hline \multirow[t]{3}{*}{ K-CDSS } & $8.3684 \pm 5.639$ & $7.063 \pm 5.240$ & 0.313 \\
\hline & \multicolumn{3}{|c|}{ A3081T } \\
\hline & $\mathrm{T} / \mathrm{T}(\mathrm{N}=31)$ & $\mathrm{A} / \mathrm{T}(\mathrm{N}=92)+\mathrm{A} / \mathrm{A}(\mathrm{N}=40)$ & p-value \\
\hline PANSS total score & $93.807 \pm 21.885$ & $97.522 \pm 21.007$ & 0.380 \\
\hline PANSS positive score & $23.936 \pm 5.543$ & $26.136 \pm 7.069$ & 0.107 \\
\hline PANSS negative score & $21.161 \pm 7.672$ & $23.418 \pm 7.973$ & 0.153 \\
\hline PANSS general score & $48.710 \pm 12.169$ & $47.955 \pm 10.566$ & 0.729 \\
\hline \multirow[t]{3}{*}{ K-CDSS } & $6.677 \pm 4.867$ & $7.341 \pm 5.390$ & 0.531 \\
\hline & \multicolumn{3}{|c|}{ G1287A } \\
\hline & $\mathrm{A} / \mathrm{A}(\mathrm{N}=20)$ & $\mathrm{G} / \mathrm{A}(\mathrm{N}=60)+\mathrm{G} / \mathrm{G}(\mathrm{N}=83)$ & p-value \\
\hline PANSS total score & $97.600 \pm 20.425$ & $96.706 \pm 21.326$ & 0.860 \\
\hline PANSS positive score & $25.650 \pm 5.976$ & $25.727 \pm 6.978$ & 0.962 \\
\hline PANSS negative score & $23.050 \pm 6.700$ & $22.993 \pm 8.124$ & 0.976 \\
\hline PANSS general score & $48.900 \pm 12.473$ & $47.986 \pm 10.652$ & 0.725 \\
\hline K-CDSS & $9.700 \pm 5.469$ & $6.867 \pm 5.185$ & 0.024 \\
\hline
\end{tabular}

PANSS: Positive and Negative Syndrome Scale, K-CDSS: Korean version of Calgary depression scale for schizophrenia

phrenia in the Polish population (198 patients and 100 controls) and failed to find any positive findings in either sex.

In the present study, we found no significant differences in the genotype or allele frequency between patients and controls for any of the three NET SNPs. The absence of associations was also observed when male and female subjects were analyzed separately. Our results are in accordance with the Polish study. We also found no significant association between haplotype combinations and schizophrenia in a threelocus haplotype analysis. In relation to clinical assessment with G1287A, A/A carriers showed higher K-CDSS score than patients without the A/A genotype ( $\mathrm{p}$-value=0.024). Al- though this suggests that schizophrenia patients with A/A have more depressive symptoms in the acute phase, the interpretation should be done carefully due to our small sample size and multiple comparison problem.

Currently, no evidence suggests that drugs related to norepinephrine reuptake improve the core symptoms of schizophrenia. If NET is involved in the pathogenesis of schizophrenia, drugs related to NET should improve the clinical symptoms. Antidepressant add-on in patients with schizophrenia is restrictively attempted to reduce depressive symptoms, and antidepressants involving norepinephrine reuptake are not preferred because of the potential risk of aggravating 
psychotic symptoms. Poyurovsky et al.$^{30}$ reported that the selective norepinephrine reuptake inhibitor reboxetine did not significantly change patient cognitive performance compared to placebo. However, such trials aim to improve the core deficit symptoms using agents involved in the neurotransmitter mechanism and thought to be important in the treatment of schizophrenia.

This study has several limitations. First, the sample size was not large enough. Second, the subjects of our study were all Korean people. Third, antipsychotic agents were not under experimental control. Even though this study has many weak points, it could serve as an important basis for future study.

\section{Conclusion}

Our results suggest that polymorphisms of the NET gene we investigate are not associated with susceptibility to schizophrenia or its clinical features in a Korean population. However, it is significant because it is the first haplotype study to investigate associations between NET gene (SLC6A2) single nucleotide polymorphisms and schizophrenia in a Korean population. Future research with a larger sample size and more genetic markers is needed to replicate our results.

\section{REFERENCES}

1. Leszczyńska-Rodziewicz A, Czerski PM, Kapelski P, Godlewski S, Dmitrzak-Weglarz M, Rybakowski J, et al. A polymorphism of the norepinephrine transporter gene in bipolar disorder and schizophrenia: lack of association. Neuropsychobiology 2002;45:182-185.

2. Wang YM, Xu F, Gainetdinov RR, Caron MG. Genetic approaches to studying norepinephrine function: knockout of the mouse norepinephrine transporter gene. Biol Psychiatry 1999;46:1124-1130.

3. Xu F, Gainetdinov RR, Wetsel WC, Jones SR, Bohn LM, Miller GW, et al. Mice lacking the norepinephrine transporter are supersensitive to psychostimulants. Nat Neurosci 2000;3:465-471.

4. Uhl GR, Johnson PS. Neurotransmitter transporters: three important gene families for neuronal function. J Exp Biol 1994;196:229-236.

5. King SC, Tiller AA, Chang AS, Lam DM. Differential regulation of the imipramine-sensitive serotonin transporter by cAMP in human JAr choriocarcinoma cells, rat PC12 pheochromocytoma cells, and C3314-B1 transgenic mouse fibroblast cells. Biochem Biophys Res Commun 1992;183:487-491.

6. Figlewicz DP, Szot P, Israel PA, Payne C, Dorsa DM. Insulin reduces norepinephrine transporter mRNA in vivo in rat locus coeruleus. Brain Res 1993;602:161-164.

7. Brüss M, Kunz J, Lingen B, Bönisch H. Chromosomal mapping of the human gene for the tricyclic antidepressant-sensitive noradrenaline transporter. Hum Genet 1993;91:278-280.

8. Porzgen P, Bonisch H, Bruss M. Molecular cloning and organization of the coding region of the human norepinephrine transporter gene. Biochem Biophys Res Commun 1995;215:1145-1150.

9. Pörzgen P, Bönisch H, Hammermann R, Brüss M. The human noradrenaline transporter gene contains multiple polyadenylation sites and two alternatively spliced C-terminal exons. Biochimet Biophys Acta 1998;1398:365-370.

10. Giros B, Wang YM, Suter S, McLeskey SB, Pifl C, Caron MG. Delineation of discrete domains for substrate, cocaine, and tricyclic antidepressant interactions using chimeric dopamine-norepinephrine trans- porters. J Biol Chem 1994;269:15985-15988.

11. Vandenbergh DJ, Persico AM, Uhl GR. A human dopamine transporter cDNA predicts reduced glycosylation, displays a novel repetitive element and provides racially-dimorphic TaqI RFLPs. Brain Res Mol Brain Res 1992;15:161-166.

12. Lesch KP, Wolozin BL, Estler HC, Murphy DL, Riederer P. Isolation of a cDNA encoding the human brain serotonin transporter. J Neural Transm Gen Sect 1993;91:67-72.

13. Ramamoorthy S, Bauman AL, Moore KR, Han H, Yang-Feng T, Chang AS, et al. Antidepressant- and cocaine-sensitive human serotonin transporter: molecular cloning, expression, and chromosomal localization. Proc Natl Acad Sci U S A 1993;90:2542-2546.

14. Kim CH, Kim HS, Cubells JF, Kim KS. A previously undescribed intron and extensive 5' upstream sequence, but not Phox2a-mediated transactivation, are necessary for high level cell type-specific expression of the human norepinephrine transporter gene. J Biol Chem 1999;274:6507-6518.

15. Inoue K, Itoh K, Yoshida K, Shimizu T, Suzuki T. Positive association between T-182C polymorphism in the norepinephrine transporter gene and susceptibility to major depressive disorder in a japanese population. Neuropsychobiology 2004;50:301-304.

16. Haenisch B, Linsel K, Brüss M, Gilsbach R, Propping P, Nothen MM, et al. Association of major depression with rare functional variants in norepinephrine transporter and serotonin1A receptor genes. Am J Med Genet B Neuropsychiatr Genet 2009;150B:1013-1016.

17. Lee YJ, Hohoff C, Domschke K, Sand P, Kuhlenbaumer G, Schirmacher A, et al. Norepinephrine transporter (NET) promoter and 5'-UTR polymorphisms: association analysis in panic disorder. Neurosci Lett 2005;377:40-43.

18. Zill P, Engel R, Baghai TC, Juckel G, Frodl T, Muller-Siecheneder F, et al. Identification of a naturally occurring polymorphism in the promoter region of the norepinephrine transporter and analysis in major depression. Neuropsychopharmacology 2002;26:489-493.

19. Stöber G, Nöthen MM, Pörzgen P, Brüss M, Bönisch H, Knapp M, et al. Systematic search for variation in the human norepinephrine transporter gene: identification of five naturally occurring missense mutations and study of association with major psychiatric disorders. Am J Med Genet 1996;67:523-532.

20. American Psychiatric Association. Diagnostic and Statistical Manual of Mental Disorders. 4th Edition. Washington, DC: American Psychiatric Association; 1994.

21. First MB, Spitzer RL, Gibbon M, Williams JBW. Structured Clinical Interview for DSM-IV-TR Axis I Disorders, Research Version, Patient Edition (SCID-I/P). New York: Biometrics Research; 2002.

22. Beck AT, Ward CH, Mendelson M, Mock J, Erbaugh J. An inventory for measuring depression. Arch Gen Psychiatry 1961;4:561-571.

23. Spielberger CD, Gorsuch RL, Lushene PR, Vagg PR, Jacobs AG. Manual for the State-Trait Anxiety Inventory (Form Y). Palo Alto: Consulting Psychologists Press, Inc; 1983.

24. Kay SR, Fiszbein A, Opler LA. The positive and negative syndrome scale (PANSS) for schizophrenia. Schizophr Bull 1987;13:261-276.

25. Addington D, Addington J, Atkinson M. A psychometric comparison of the Calgary Depression Scale for Schizophrenia and the Hamilton Depression Rating Scale. Schizophr Res 1996;19:205-212.

26. Kim YK, Won SD, Lee KM, Choi HS, Jang HS, Lee BH, et al. A study on the reliability and validity of the Korean version of the Calgary Depression Scale for Schizophrenia (K-CDSS). J Korean Neuropsychiatr Assoc 2005;44:446-455.

27. Suzuki A, Matsumoto Y, Ishii G, Oshino S, Goto K, Otani K. No association between the $-3081 \mathrm{~A} / \mathrm{T}$ polymorphism in the norepinephrine transporter gene promoter and personality traits in healthy subjects. Neurosci Lett 2007;425:192-194.

28. Cordeiro Q, Vallada H. Lack of association between a polymorphism of the norepinephrine transporter gene and schizophrenia in a Brazilian sample. Rev Bras Psiquiatr 2004;26:278. 
29. Siuta MA, Robertson SD, Kocalis H, Saunders C, Gresch PJ, Khatri V, et al. Dysregulation of the norepinephrine transporter sustains cortical hypodopaminergia and schizophrenia-like behaviors in neuronal rictor null mice. PLoS Biol 2010;8:e1000393.
30. Poyurovsky M, Faragian S, Fuchs C, Pashinian A. Effect of the selective norepinephrine reuptake inhibitor reboxetine on cognitive dysfunction in schizophrenia patients: an add-on, double-blind placebocontrolled study. Isr J Psychiatry Relat Sci 2009;46:213-220. 